\title{
'PENGEMBANGAN BUKU AJAR BERORIENTASI PENDIDIKAN KARAKTER PADA MATA KULIAH PEMBELAJARAN PKn SD DI PROGRAM STUDI S1 PGSD ${ }^{\text {ii }}$
}

\author{
Sri Suwartini, M.Pd PGSD Unwidha \\ sri_t2n@yahoo.co.id
}

\begin{abstract}
Textbooks have become the main element of teaching and learning process. Studies have been conducted to develop instructional materials for the subject of PKn SD at Elementary School Teacher Training Study Program, but there is still limited textbooks with character content, when character have been debating recently. This research is attempetd to develop textbook of PKn SD with character content, by measuring students' activity, achievement and response. This research is cunducted by class evaluation research method by applying 4-D model. The subjects of the research are 20 students of $5 D$ and 20 of 5I, PGSD Unwidha Klaten. The results of the research shows that: the learning activity is good by $77.6 \%$ of sctive students; $95 \%$ of students achieve threshold level by 80.75; textbook is suitable used in average $83.2 \%$ and have positive response against the textbook.
\end{abstract}

Keywords: Textbook, character education, PKn SD.

\begin{abstract}
Abstrak
Buku ajar menjadi unsur utama dalam proses belajar mengajar. Hasil studi yang telah dilakukan menunjukkan buku ajar PKn SD di Program Studi Pendidikan Guru Sekolah Dasar masih minim muatan karakter, dimana karakter menjadi perdebatan hangat saat ini. Penelitian ini mencoba untuk mengembangkan buku ajar PKn SD dengan konten karakter, dengan mengukur aktivitas siswa, prestasi dan respon mahasiswa. Penelitian ini dilakukan dengan metode penelitian evaluasi kelas dengan menerapkan model 4-D. Subyek penelitian adalah 20 mahasiswa semester 5D dan 20 mahasiswa kelas 5I Program Studi PGSD Unwidha Klaten. Hasil penelitian menunjukkan bahwa: aktivitas pembelajaran baik dengan 77,6\% siswa aktif, 95\% siswa mencapai ketuntasan dengan rata-rata 80,75; bahan ajar layak digunakan dengan rata-rata $83,2 \%$ dan mahasiswa memberi respon positif terhadap buku ajar.
\end{abstract}

Kata Kunci : Buku Ajar, Pendidikan Karakter, PKn SD 


\section{A. Pendahuluan}

Mata kuliah Pendidikan Kewarganegaraan (PKn) SD merupakan salah satu mata kuliah yang wajib diprogramkan oleh mahasiswa S1 PGSD Fakultas Ilmu Pendidikan Unwidha Klaten. Sebagai salah satu mata kuliah bidang studi, Pembelajaran PKn SD bertujuan untuk memberikan keterampilan, kemampuan dasar mengajar dan pemahaman mahasiswa dalam menerapkan metode dan strategi pembelajaran PKn di Sekolah Dasar yang didasari prinsip-prinsip pembelajaran yang mendidik dan bermuatan nilai, norma, moral serta pendidikan karakter berikut kegiatan evaluasi hasil belajarnya.

Buku ajar merupakan salah satu bahan ajar tulis dan mempunyai peranan penting dalam kegiatan pembelajaran. Berdasarkan Permendiknas No. 2 Tahun 2008 mengenai buku teks, pada pasal 1 dijelaskan bahwa buku adalah acuan wajib untuk digunakan di satuan pendidikan dasar dan menengah atau perguruan tinggi yang memuat materi pembelajaran dalam rangka peningkatan keimanan, ketakwaan, akhlak mulia, dan kepribadian, penguasaan ilmu pengetahuan dan teknologi, peningkatan kepekaan dan kemampuan estetis, peningkatan kemampuan kinestetis dan kesehatan yang disusun berdasarkan Standar Nasional Pendidikan.

Menurut Bacon dalam (Tarigan, 1986:11), buku dirancang untuk digunakan di kelas, dengan cermat disusun dan disiapkan oleh para pakar atau para ahli dalam bidang itu dan dilengkapi dengan sarana-sarana pengajaran yang sesuai dan serasi. Secara umum, buku berfungsi sebagai sarana penting dan ampuh bagi penyediaan serta pemenuhan pembelajaran. Buku memiliki peran penting dalam sistem pendidikan nasional, karena dapat memberikan pengaruh besar terhadap kesatuan nasional melalui pendirian serta pembentukan suatu kebudayaan umum. Sebagai media pengajaran, buku pelajaran merupakan media yang strategis dalam mentransformasikan ilmu pengetahuan serta nilai-nilai kehidupan, budaya, dan karakter (moral dan kepriibadian) bagi para peserta didik.

Buku ajar yang digunakan untuk pegangan mahasiswa harus terus diupdate dari segi kurikuler, isi, maupun bahasa agar sesuai dengan perkembangan pengetahuan dan kurikulum yang digunakan. Kurikulum yang sering berganti dalam waktu relatif cepat sebagai konsekuensi kebutuhan dunia pendidikan 
terhadap manusia sebagai subjek karya, karena itu belum tentu dapat diikuti dengan kecepatan pengadaan buku ajar untuk mahasiswa.

Dari uraian tersebut, dosen/guru seharusnya mampu mengembangkan buku ajar sendiri sebagai salah satu sumber belajar lain di samping buku teks mahasiswa. Dalam Peraturan Pemerintah Nomor 19 Tahun 2005 Pasal 20, bahwa guru/dosen diharapkan mengembangkan materi pembelajaran dan melalui Permendiknas Nomor 41 Tahun 2007 tentang Standar Proses mengatur perencanaan proses pembelajaran bagi pendidik pada satuan pendidikan untuk mengembangkan RPP dan bahan ajar. Semua itu harus melalui beberapa proses pengkajian. Proses pengkajian ini mengacu pada instrumen penilaian buku dari BSNP.

Menurut Panen dan Purwanto (2004) bahan ajar atau buku ajar berbeda dengan buku teks. Perbedaan antara bahan ajar atau buku ajar dengan buku teks tidak hanya terletak pada format, tata letak dan perwajahannya, tetapi juga pada orientasi dan pendekatan yang digunakan dalam penyusunannya. Buku teks biasanya ditulis dengan orientasi pada struktur dan urutan berdasarkan bidang ilmu (content oriented) untuk dipergunakan oleh dosen atau guru dalam mengajar (teaching oriented). Sangat jarang buku teks dipergunakan untuk belajar mandiri, karena Dengan demikian, penggunaan buku teks memerlukan dosen atau guru yang berfungsi sebagai penterjemah yang menyampaikan isi buku tersebut bagi peserta didik memang tidak dirancang untuk itu. Buku ajar mempunyai perbedaan dengan buku teks, Buku ajar merupakan bahan atau materi pembelajaran disusun secara sistematis yang digunakan guru dan mahasiswa dalam Kegiatan Belajar Mengajar, sedangkan buku teks merupakan sumber informasi yang disusun dengan struktur dan urutan berdasar bidang ilmu tertentu.

Pemanfaatan sumber belajar mempunyai pengaruh terhadap hasil belajar mahasiswa. Studi pendahuluan yang dilakukan pada semester gasal 2013/2014 di Program Studi S1 PGSD Unwidha Klaten dalam pemanfaatan buku ajar untuk mata kuliah pembelajaran PKn SD, mahasiswa hanya menggunakan buku teks bidang ilmu tertentu sebagai sumber belajar dengan hasil ketercapaian tujuan pembelajaran yang masih belum optimal, dikarenakan mahasiswa hanya mendapatkan sumber informasi dari buku teks saja. Di samping itu, aktivitas 
mahasiswa dalam pembelajaran masih kurang aktif. Saat ini, sumber belajar yang digunakan adalah buku teks bidang ilmu tertentu. Oleh karenanya, diperlukan sumber belajar lain yang sesuai dengan materi perkuliahan untuk memperluas wawasan pemahaman dan keterampilan mahasiswa tentang materi pembelajaran PKn SD. Dengan wawasan pemahaman dan keterampilan yang luas mahasiswa dapat mengimplementasikan kemampuanya dengan baik dalam proses pembelajaran di Sekolah Dasar.

Permasalahan budaya dan karakter bangsa kini menjadi topik perbincangan dan sorotan tajam masyarakat. Sorotan itu mengenai berbagai aspek kehidupan, yang tertuang dalam berbagai tulisan di media cetak, wawancara, dialog, dan gelar wicara di media elektronik. Persoalan yang muncul di masyarakat seperti korupsi, kekerasan, kejahatan seksual, perusakan, perkelahian massa, kehidupan ekonomi yang konsumtif, kehidupan politik yang tidak produktif, dan sebagainya menjadi topik pembahasan hangat di media massa, seminar, dan di berbagai kesempatan.

Pendidikan dianggap sebagai alternatif yang bersifat preventif, karena pendidikan membangun generasi baru bangsa yang lebih baik. Sebagai alternatif yang bersifat preventif, pendidikan diharapkan dapat mengembangkan kualitas generasi muda bangsa dalam berbagai aspek yang dapat mengurangi penyebab berbagai masalah budaya dan karakter bangsa. Memang diakui bahwa hasil dari pendidikan akan terlihat dampaknya dalam waktu yang tidak segera, tetapi memiliki daya tahan dan dampak yang kuat di masyarakat.

Keinginan masyarakat dan kepedulian pemerintah mengenai pendidikan budaya dan karakter bangsa, akhirnya berakumulasi pada kebijakan pemerintah mengenai pendidikan budaya dan karakter bangsa dan menjadi salah satu program unggulan pemerintah di bidang pendidikan. Terkait dengan mata kuliah Pembelajaran PKn SD, secara programatik PKn dirancang sebagai subjek pembelajaran yang menekankan pada isi yang mengusung nilai-nilai (content embedding values) dan pengalaman belajar (learning experiences) dalam bentuk berbagai perilaku yang perlu diwujudkan dalam kehidupan sehari-hari dan merupakan tuntunan hidup bagi warga negara dalam kehidupan bermasyarakat, berbangsa, dan bernegara sebagai penjelasan lebih lanjut dari ide, nilai, konsep, 
dan moral Pancasila, kewarganegaraan yang demokratis, dan bela negara (Winataputra dan Budimansyah, 2007). Jika memperhatikan uraian tersebut, maka tampak bahwa PKn merupakan program pendidikan yang sangat penting untuk upaya pembangunan karakter bangsa.

Konsekuensi dari prinsip ini, nilai-nilai budaya dan karakter bangsa tidak ditanyakan dalam ujian. Walaupun demikian, mahasiswa perlu mengetahui pengertian dari suatu nilai yang sedang mereka tumbuhkan (Kemendiknas, 2010:12-13). Pengembangan nilai-nilai pendidikan budaya dan karakter bangsa tidak dijadikan pokok bahasan yang dikemukakan dalam mata kuliah, namun dapat diintegrasikan dalam setiap pokok bahasan dari setiap materi pembelajaran. Aspek-aspek pendidikan karakter khususnya nilai Ketuhanan dan kesosialan sangatlah penting untuk dipahami mahasiswa seiring dengan perkembangan di era globalisasi agar nilai-nilai karakter bangsa tidak mengalami kemerosotan. Adanya perubahan implementasi kurikulum dari KTSP menjadi kurikulum 2013 yang menekankan pada penanaman nilai-nilai karakter inilah yang menuntut seorang pendidik khusunya dosen untuk mampu mengembangkan buku ajar yang berorientasi pendidikan karakter sebagai pedoman belajar mahasiswa yang dapat memberikan pemahaman kepada mahasiswa tentang implementasi nilai-nilai karakter yang nantinya dapat di terapkan dalam pembelajaran kepada siswanya di Sekolah Dasar.

\section{B. Pembahasan}

\section{Bahan Ajar}

Buku ajar pembelajaran adalah bahan ajar yang disusun secara sistematis dan menarik yang mencakup isi materi, metode dan evaluasi yang dapat digunakan secara mandiri untuk mencapai kompetensi yang diharapkan (Anwar, 2010). Sebagai salah satu bahan ajar cetak, buku ajar merupakan suatu paket belajar yang berkenaan dengan satu unit bahan pelajaran. Dengan buku ajar mahasiswa dapat mencapai dan menyelesaikan bahan belajarnya dengan belajar secara individual. Buku ajar dapat dipelajari di mana saja dan kapan saja kita mau. Akan tetapi keleluasaan mahasiswa mengelola waktu tersebut sangat fleksibel, dapat beberapa menit dan dapat pula beberapa jam, dan dapat dilakukan secara tersendiri atau diberi variasi dengan metode lain Ada tiga 
teknik yang dapat dipilih dalam menyusun buku ajar. Ketiga teknik tersebut menurut Sungkono, dkk (2003:19) yaitu menulis sendiri, pengemasan kembali informasi dan penataan informasi

a. Menulis sendiri (starting from scracth)

Penulis/dosen dapat menulis sendiri buku ajar yang akan digunakan dalam proses pembelajaran. Asumsi yang mendasari cara ini adalah bahwa dosen adalah pakar yang berkompeten dalam bidang ilmunya, mempunyai kemampuan menulis, dan mengetahui kebutuhan mahasiswa dalam bidang ilmu tersebut.

b. Pengemasan kembali informasi (information repackaging)

Penulis/dosen tidak menulis buku ajar sendiri, tetapi memanfaatkan bukubuku teks dan informasi yang telah ada dipasaran untuk dikemas kembali menjadi buku ajar yang memenuhi karakteristik buku ajar yang baik. Buku ajar atau informasi yang sudah ada dikumpulkan berdasarkan kebutuhan (sesuai dengan kompetensi, silabus dan SAP), kemudian disusun kembali dengan gaya bahasa yang sesuai. Selain itu juga diberi tambahan keterampilan, kemampuan atau kompetensi yang akan dicapai, latihan, tes formatif dan umpan balik.

c. Penataan informasi (compilation)

Cara ini mirip dengan cara kedua, tetapi dalam penataan kembali informasi tidak ada perubahan yang dilakukan terhadap buku ajar yang diambil dari buku teks, jurnal ilmiah, artikel dan lain-lain. Dengan kata lain, materi-materi tersebut dikumpulkan, digandakan dan digunakan secara langsung. Materimateri tersebut dipilih, dipilah, dan disusun berdasarkan kompetensi yang akan dicapai dan silabus yang hendak digunakan dalam proses perkuliahan.

2. Hasil Belajar

Belajar adalah suatu proses dan aktivitas yang selalu dilakukan dan dialami manusia sejak manusia didalam kandungan, buaian, tumbuh berkembang dari anak-anak, remaja sehingga menjadi dewasa, sampai ke lianglahat, sesuai dengan prinsip pembelajaran sepanjang hayat.

Hasil belajar merupakan bagian terpenting dalam pembelajaran. Nana Sudjana (2009: 3) mendefinisikan hasil belajar pada hakikatnya adalah 
perubahan tingkah laku sebagai hasil belajar dalam pengertian yang lebih luas mencakup bidang kognitif, afektif, dan psikomotorik.

Hasil belajar dalam penelitian ini sesuai dengan rancangan penelitian yang termasuk dalam domain kognitif dan afektif. Hasil belajar diukur dengan soal tes formatif dalam buku ajar yang dikembangkan dan dari segi pengamatan dosen terhadap aktivitas dan instrumen angket respon mahasiswa yang telah disusun mengacu pada tujuan pembelajaran dalam satuan acara perkuliahan. Bloom dan kawan-kawan dalam Ibrahim (2010) membagi hasil belajar/kemampuan manusia ke dalam tiga ranah (domain) yaitu kognitif, psikomotor dan afektif. Ketuntasan belajar merupakan salah satu muatan Kurikulum Perguruan Tinggi yang telah ditetapkan. Standart ketuntasan belajar mahasiswa ditentukan dari hasil prosentase penguasaan mahasiswa pada kompetensi dasar dalam suatu materi tertentu. Kriteria ketuntasan belajar setiap kompetensi dasar berkisar antara 0\%-100\%.

Menurut Permendiknas No. 22 tahun 2006 dalam standard isi idealnya untuk masing-masing indikator mencapai 75\%. Berdasarkan hal itu, dapat disimpulkan bahwa ketuntasan belajar secara berkelanjutan sampai mendekati ideal

\section{Aktivitas belajar Mahasiswa}

Aktivitas adalah segala sesuatu yang dilakukan atau kegiatan-kegiatan yang terjadi baik fisik maupun non fisik (Mulyono, 2001:26). Jadi aktivitas mahasiswa adalah segala kegiatan yang dilakukan baik secara jasmani atau rohani dalam prose pembelajaran. Aktivitas mahasiswa selama proses belajar merupakan salah satu indikator adanya keinginan mahasiswa untuk belajar.

Berdasarkan penjelasan di atas dapat disimpulkan bahwa aktivitas belajar merupakan segala kegiatan yang dilakukan dalam proses interaksi (dosen dan mahasiswa) dalam rangka mencapai tujuan belajar. Aktivitas yang dimaksudkan disini penekanannya adalah pada mahasiswa, sebab dengan adanya aktivitas mahasiswa dalam proses pembelajaran terciptalah situasi belajar aktif.

\section{Respon Mahasiswa}


Menurut Berlo (dalam Sutisna Senjaya, 2010:1), bahwa respon sebagai sesuatu yang dikerjakan oleh seseorang sebagai hasil atau akibat menerima stimulus. Stimulus tersebut merupakan sesuatu yang dapat diterima oleh seseorang melalui salah satu penginderanya.

Dalam satu komunitas tertentu ada beberapa respon yang berbeda. Seperti diketahui bahwa selama kegiatan belajar berlangsung, maka akan tampak berbagai macam respon yang diberikan mahasiswa. Sebagai contoh respon dapat ditunjukkan melalui tindakan mahasiswa. Tindakan respon mahasiswa dapat merubah perilaku mahasiswa yang pada awalnya pasif diharapkan bisa lebih aktif dalam menanggapi materi yang diajarkan oleh dosen. Adanya respon mahasiswa dalam kegiatan belajar mengajar, maka bisa diyakini bahwa kegiatan belajar mengjar yang efektif dan kondusif bisa terwujud (Siti Hanim, 2011:1)

\section{METODE PENELITIAN \\ 1. Jenis Penelitian}

Penelitian ini merupakan Penelitian Pengembangan (Research and Development), karena mengembangkan Buku Ajar Berorientasi Pendidikan Karakter Pada Mata kuliah Pembelajaran PKn SD di Program Studi S1 PGSD untuk meningkatkan pemahaman, keterampilan dan kemampuan dasar mengajar mahasiswa Program Studi S1 PGSD Unwidha Klaten.. Menurut Borg and Gall (1983) bahwa penelitian dan pengembangan (Research and Development) merupakan penelitian yang digunakan untuk mengembangkan atau memvalidasi produk-produk yang digunakan dalam pendidikan dan pembelajaran

2. Prosedur Penelitian

Pengembangan Buku Ajar Berorientasi Pendidikan Karakter Pada Mata kuliah Pembelajaran PKn SD di Program Studi S1 PGSD ini menggunakan Four-D Model yang dikemukakan Thiagarajaan Semmel dan Samuel (dalam Ibrahim, 2002) yaitu define (pendefinisian), design (perancangan), develop (pengembangan), dan dessiminate (penyebaran) yang diadaptasi menjadi Model 4-P, yaitu Pendefinisian, Perancangan, Pengembangan, dan Penyebaran (Ibrahim,2002:97). Dalam penelitian ini 
pengembangan buku ajar disederhanakan hanya sampai pada tahap develop tanpa tahap disseminate, sehingga buku ajar yang telah dikembangkan hanya digunakan pada Prodi S1 PGSD Unwihda Klaten saja sebagai tempat uji coba, tanpa disebarkan pada Perguruan Tinggi lain.

\section{Variabel Penelitian}

Berdasarkan rumusan masalah yang terdapat pada Bab I maka variabel yang diamati dalam penelitian ini adalah,

1.Validitas bahan ajar atau buku ajar

2.Aktivitas mahasiswa

3.Respon mahasiswa

4.Hasil belajar mahasiswa

\section{Instrumen Penelitian}

Instrumen penelitian merupakan alat yang digunakan untuk mengumpulkan data penelitian. Instrumen yang digunakan dalam penelitian ini adalah,

1. Lembar Penilaian Buku Ajar

2. Lembar Pengamatan Keterlaksanaan SAP

3. Lembar pengamatan aktivitas mahasiswa

4. Tes hasil belajar

\section{Teknik Pengumpulan Data}

Teknik pengumpulan data adalah suatu cara yang digunakan peneliti untuk mengumpulkan data penelitian. Pengumpulan data dalam penelitian ini menggunakan teknik observasi dan pemberian tes hasil belajar mahasiswa.

\section{Observasi}

2. Pemberian Tes Hasil Belajar Mahasiswa

\section{Teknik Analisis}

1. Analisis Validitas Bahan Ajar atau Buku Ajar

2. Analisis Pelaksanaan Pembelajaran 
3. Analisis Aktivitas Mahasiswa

4. Analisis Respon Mahasiswa

5. Analisis Hasil Belajar Mahasiswa

6. Analisis Data Keefektifan Buku Ajar

\section{Hasil Penelitian Dan Pembahasan}

\section{Validasi Buku Ajar}

Penelitian ini merupakan penelitian pengembangan (Research and development). Bahan ajar yang dikembangkan adalah Buku Ajar Berorientasi Pendidikan Karakter Pada Mata kuliah Pembelajaran PKn SD di Program Studi S1 PGSD. Buku ajar yang telah dikembangkan divalidasi oleh ahli materi, kebahasaan, penyajian dan kegrafikaan pengembangan dan analisis materi pembelajaran $\mathrm{PKn}$ SD, pengertian endekatan, strategi dan metode dalam pembelajaran $\mathrm{PKn}$ SD, media pembelajaran $\mathrm{PKn}$ SD, evaluasi pembelajaran PKn SD dan penyusunan perangkat pembelajaran PKn SD. Pada setiap sub materi dilengkapi dengan karakter yang ditumbuhkan sesuai dengan indikator pembelajaran.

Berdasarkan hasil validasi pada buku ajar untuk aspek materi ajar mendapatkan nilai total 32 dengan persentase sebesar $80 \%$. Nilai tersebut menunjukkan bahwa komponen materi ajar dalam buku ajar yang dikembangkan memenuhi kriteria untuk di uji cobakan dalam proses perkuliahan dengan kriteria baik atau layak. Sedangkan untuk aspek penyajian buku ajar yang dikembangkan mendapat skor total 20 dengan persentase sebesar $83,3 \%$. Hal tersebut menunjukkan bahwa dari segi penyajian buku ajar yang dikembangkan memenuhi kriteria penyajian untuk di uji cobakan dengan kriteria sangat baik atau sangat layak.

Pada aspek kebahasaan buku ajar yang dikembangkan mendapat skor total sebesar 27 dengan persentase sebesar $84,4 \%$. Hal tersebut menunjukkan bahwa dari segi aspek kebahasaan buku ajar yang dikembangkan sudah sangat layak untuk di ujicobakan dalam proses pembelajaran dengan kriteria sangat baik atau sangat layak. Sedangkan untuk aspek kegrafikaan buku ajar yang dikembangkan mendapat skor total 64 dengan persentase sebesar $84,2 \%$. Hal tersebut menunjukkan bahwa dari segi kegrafikaan buku ajar 
yang dikembangkan memenuhi kriteria untuk di uji cobakan dengan kriteria sangat baik atau sangat layak.

Secara keseluruhan untuk hasil validasi buku ajar yang dikembangkan mendapatkan skor total sebesar 143 dengan persentase sebesar 83,2\%. Secara keseluruhan tim validasi buku ajar memberikan penilaian bahwa buku ajar yang dikembangkan sangat baik atau sangat layak untuk di uji cobakan dalam proses pembelajaran.

\section{Validasi SAP (Satuan Acara Perkuliahan)}

Satuan Acara Perkuliahan yang telah disusun terdiri dari tiga komponen yaitu pendahuluan/kegiatan awal, kegiatan inti dan kegiatan penutup. Dari masing-masing komponen tersebut terdiri dari poin-poin sub komponen. Jumlah SAP yang disusun ada lima buah, tiap SAP untuk satu kali pertemuan. Aspek pertama yang ada dalam validasai SAP adalah format Satuan Acara Perkuliahan. Adapun komponen tersebut adalah sistem penomoran, Pengaturan ruang tata letak, Jenis font dan ukuran huruf sesuai, Pembagian waktu sesuai dengan materi. Secara keseluruhan, aspek format SAP memperoleh skor rata-rata sebesar 13,5 dengan reliabilitas sebesar $84,4 \%$. Dengan demikian kriteria format SAP tersebut termasuk dalam kategori sangat baik atau sangat layak untuk dilaksanakan.

Aspek isi yang berisikan kejelasan perumusan tujuan pembelajaran, pemilihan materi ajar, pengorganisasian materi ajar, pemilihan sumber/media pembelajaran, kejelasan skenario pembelajaran, kerincian skenario pembelajaran, kesesuaian teknik dengan tujuan pembelajaran, mendapat skor rata-rata sebanyak 23,5, yang mempunyai reliabilitas sebanyak 83,9\%. Hal ini menjelaskan bahwa aspek isi dalam SAP berkualitas sangat baik dan mudah dipahami. Aspek bahasa yang berisikan kebenaran tata bahasa, ketepatan struktur kalimat, kejelasan petunjuk, dan bahasa yang komunikatif penilaian pada aspek ini mendapatkan skor ratarata sebesar 13,5 poin, yang mempunyai reliabilitas $84,4 \%$. Hal ini menjelaskam bahwa aspek bahasa dalam SAP berkualitas sangat baik.

Secara keseluruhan total nilai rata-rata perangkat pembelajaran pada SAP pembelajaran $\mathrm{PKn}$ SD, berjumlah 50,5 poin, yang mempunyai reliabilitas 
84,2\%. Hal ini menjelaskan bahwa perangkat pembelajaran SAP pembelajaran PKn SD mempunyai kategori sangat baik dan sangat layak untuk dilaksanakan

\section{Implementasi Buku Ajar Berorientasi Pendidikan Karakter Pada Mata Kuliah Pembelajaran PKn SD di Program Studi S1 PGSD}

\section{Hasil Pengamatan Aktivitas Dosen}

Aktivitas dosen di kelas 5I yang pertama adalah melakukan apersepsi melalui tanya jawab dengan mahasiswa tentang tema pembelajaran dalam tiap unit pada buku ajar yang dikembangkan. Aktivitas ini mendapat nilai rata-rata sebesar 4 dengan persentase 100\%. Aktivitas dosen dalam menyampaikan tujuan pembelajaran sesuai dengan SAP mendapat skor rata-rata 3,8 dengan persentase $95 \%$. Aktivitas dosen selanjutnya adalah memberikan wawasan tentang pentingnya kompetensi dasar dan melatih mahasiswa berani menyampaikan pikiran, perasaan dan pengalaman secara lisan. Aktivitas ini mendapat skor rata-rata 3,8 dengan persentase 95\%.. Aktivitas dosen selanjutnya adalah mengaitkan tema pembelajaran dengan kompetensi dasar yang harus dikuasai oleh mahasiswa pada tiap unit pada buku ajar yang dikembangkan. Kegiatan ini dilakukan secara klasikal. Aktivitas ini mendapat skor rata-rata 3,3 dengan persentase $82,5 \%$.

Aktivitas dosen dalam membentuk kelompok mahasiswa dengan anggota 4 sampai 5 orang di sesuaikan dengan jumlah perempuan dan lakilaki (dengan keseluruhan jumlah mahasiswa yaitu 20 orang) mendapat skor rata-rata 4 dengan persentase $100 \%$. Aktivitas dosen yang selanjutnya adalah memanfaatkan buku ajar atau menyampaikan materi ajar yang dikembangkan dengan menggunakan kalimat yang mudah dipahami oleh mahasiswa. Aktivitas ini mendapat skor rata-rata 4 dengan persentase $100 \%$.

Aktivitas dosen dalam melakukan pengecekan hasil kelompok yang disimulasikan dalam kelompok mendapat skor rata-rata 3,8 dengan persentase 95\%. Tiga aktivitas dosen yang selanjutnya yakni memeriksa secara sekilas hasil pekerjaan mahasiswa dan membagikan rubrik penilaian kepada mahasiswa mendapat skor rata-rata 4 dengan persentase $100 \%$. Kemudian memberikan tanggapan secara umum apabila ada hal-hal yang perlu 
disepakati mendapatkan skor rata-rata 3,9 dengan persentase 97,5\%. Aktivitas dosen selanjutnya adalah melakukan refleksi dangan memberikan tugas untuk memperkuat retensi mahasiswa setelah mempelajari materi dengan memanfaatkan buku ajar, yakni bagaimana menyampaikan materi ajar agar mahasiswa dapat berbicara dengan lafal dan intonasi yang baik dan benar secara santun mendapat skor rata-rata 4 dengan persentase $100 \%$.

Dari hasil keseluruhan analisis data aktivitas dosen dan kemampuan dosen mengelola pembelajaran seperti yang ditunjukan pada Tabel 4.7 tersebut, total persentase aktivitas dosen pada pertemuan pertama mendapat skor 39 dengan persentase sebesar 97,5\% atau aktivitas dosen sangat baik dalam proses pembelajaran.

Pada pertemuan kedua aktivitas dosen mendapat skor total 38 dengan persentase sebesar $95 \%$ atau aktivitas dosen sangat baik dalam proses pembelajaran. Kemudian pada pertemuan ketiga untuk materi unit tiga aktivitas dosen mendapat skor total 39 dengan persentase sebesar 97,5\% atau aktivitas dosen sangat baik dalam proses pembelajaran.

Pada pertemuan keempat aktivitas dosen mendapat skor total 38 dengan persentase sebesar 95\% atau aktivitas dosen sangat baik dalam proses pembelajaran. Kemudian pada pertemuan terakhir aktivitas dosen mendapat skor total 39 dengan persentase sebesar 97,5\% atau aktivitas dosen sangat baik dalam proses pembelajaran.

Dengan demikian dapat disimpulkan bahwa aktivitas dosen pada penerapan pembelajaran dengan menggunakan buku ajar pada kelas 5I sebagai kelas eksperimen yang telah dikembangkan dapat dikategorikan sangat baik atau terlaksana dengan sangat baik dengan skor rata-rata total disemua pertemuan 38,6 dengan persentase total $96,5 \%$.

Dari hasil keseluruhan analisis data aktivitas dosen, keterlaksanaan SAP dan kemampuan dosen mengelola pembelajaran seperti yang ditunjukan pada Tabel 4.8 tersebut, total persentase aktivitas dosen sebanyak $96 \%$. Dengan demikian dapat disimpulkan bahwa aktivitas dosen pada 
penerapan pembelajaran tanpa menggunakan buku ajar pada kelas 5D sebagai kelas kontrol dapat dikategorikan sangat baik.

\section{2 . Hasil Pengamatan Aktivitas Mahasiswa}

Berdasarkan hasil pengamatan tim pengamat, dapat kita kemukakan bahwa aktivitas mahasiswa kelas 5I selama proses perkuliahan dengan menggunakan buku ajar yang dikembangkan setelah dirata-rata dari tiap pertemuan mempunyai rata-rata skor $75,52 \%$. Sedangkan proses perkuliahan di kelas 5D tanpa menggunakan buku ajar mempunyai skor rata-rata 58,2\%. Hal ini menujukkan aktivitas mahasiswa pada kelas 5I lebih aktif jika dibandingkan dengan kelas 5D dengan selisih sebesar $17,32 \%$.

\section{Respon Mahasiswa}

Respon mahasiswa terhadap proses pembelajaran dengan menggunakan buku ajar Pembelajaran PKn SD. Berdasarkan analisis, diketahui tanggapan mahasiswa tentang perasaan mahasiswa saat mengikuti pembelajaran dengan menggunakan buku ajar yang meliputi komponenkomponen seperti pada tabel. Untuk komponen pertama sebanyak 18 mahasiswa senang dalam mengikuti pembelajaran dengan menggunakan buku ajar atau dengan persentase sebesar $90 \%$ dan hanya 2 mahasiswa yang tidak senang atau sebesar $10 \%$ saja. Materi yang menarik dan format buku ajar yang rapi dan bagus, hal itu menarik minat mahasiswa dan lebih menghidupkan lagi suasana pembelajaran.

Hal serupa juga terjadi pada respon mahasiswa terhadap komponen yang kedua. Dari 20 mahasiswa yang mengikuti ujicoba, semua mahasiswa atau $100 \%$ mengaku senang dengan suasana perkuliahan menggunakan buku ajar. Sedangkan untuk komponen cara dosen mengajar ada 17 mahasiswa yang mengaku senang atau sebesar $85 \%$ dan hanya 3 mahasiswa yang tidak senang atau 15\%. Dengan demikian dapat dikatakan bahwa 92,5\% mahasiswa sangat senang mengikuti pembelajaran dengan menggunakan buku ajar.

Dari segi format penyajian atau penampilan buku ajar, sebagian besar respons mahasiswa menyatakan menarik. Hal itu terbukti dari 20 mahasiswa, 19 mahasiswa atau sebanyak 95\% mahasiswa menyetakan tertarik dengan 
buku ajar yang diterapkan. Sisanya, hanya satu mahasiswa atau 5\% saja mengaku tidak tertarik dengan buku ajar yang dikembangkan. Pendapat mahasiswa selanjutnya adalah tentang waktu yang mahasiswa butuhkan untuk memahami materi perkuliahan dengan menggunakan buku ajar yang dikembangkan. Berdasarkan tabel tersebut, sebanyak 17 mahasiswa atau sebesar $85 \%$ mahasiswa lebih cepat memahami materi dengan menggunakan buku ajar dan mengaku berminat dengan buku ajar yang digunakan. Hanya tiga mahasiswa atau sebanyak $15 \%$ mahasiswa saja yang menyatakan masih cukup membutuhkan waktu lama untuk memahami materi dengan menggunakan buku ajar. Respon mahasiswa selanjutnya adalah tentang pemahaman materi mata kuliah pembelajaran PKn SD apabila disajikan dengan menggunakan buku ajar. Berdasarkan data yang diperoleh, sebanyak 19 mahasiswa atau sebanyak 95\% mahasiswa menyatakan terbantu dengan adanya buku ajar yang dikembangkan untuk memahami materi perkuliahan. Sisanya, hanya satu mahasiswa saja atau sebanyak 5\% menyatakan tidak terbantu dengan adanya buku ajar yang dikembangkan untuk memahami materi perkuliahan.

Untuk respon mahasiswa yang keenam berdasarkan data yang diperoleh, semua mahasiswa atau $100 \%$ mahasiswa mengaku sangat terbantu dalam belajar dengan menggunakan buku ajar yang dikembangkan. Respon mahasiswa yang terakhir adalah tentang apakah mata kuliah pembelajaran PKn SD merupakan mata kuliah yang sulit jika dalam proses perkuliahan menggunakan buku ajar yang dikembangkan? Dari data yang diperoleh ada 18 mahasiswa atau 90\% menyatakan bahwa mata kuliah pembelajaran PKn SD merupakan mata kuliah yang tidak sulit atau mudah dipelajari. Sedangkan mahasiswa yang beranggapan mata kuliah pembelajaran PKn SD merupakan mata kuliah sulit ada 2 mahasiswa atau 10\% saja. Jadi kesimpulanya mata kuliah pembelajaran PKn SD merupakan mata kuliah yang mudah atau tidak sulit jika dalam proses perkuliahan menggunakan buku ajar.

Berdasarkan ketujuh respons mahasiswa terhadap penggunaan buku ajar yang dikembangkan, menyatakan jika buku ajar yang dikembangkan sangat menarik, menambah minat belajar mahasiswa, mudah dipahami, dan 
sangat bermanfaat untuk mahasiswa dalam mengatasi kesulitan belajar. Dengan demikian, buku ajar yang dikembangkan disetujui mahasiswa dan bisa diterapkan dalam proses perkuliahan untuk mata kuliah pembelajaran PKn SD.

4. Tes Hasil Belajar Mahasiswa

Tes hasil belajar adalah perubahan perilaku yang terjadi setelah mengikuti proses pembelajaran sesuai dengan tujuan pendidikan. Hasil belajar mahasiswa yang diharapkan setelah pembelajaran yaitu, ketuntasan mahasiswa secara individual maupun klasikal dapat tercapai. Ketercapaian ketuntasan mahasiswa ini tentu ditunjang dengan aktivitas mahasiswa selama proses pembelajaran dengan menggunakan buku ajar yang dikembangkan. Hasil belajar mahasiswa diperoleh dengan melakukan tes uji awal dan uji akhir sebelum dan sesudah pembelajaran baik dengan menggunakan buku ajar maupun tanpa menggunakan buku ajar.

Hipotesis yang telah dirumuskan diuji dengan statistik deskriptif dengan cara menuliskan jawaban sementara terhadap rumusan masalah penelitian dan dinyatakan dan dinyatakan dalam bentuk kata atau kalimat. Sebelum menganalisis data, terlebih dulu peneliti mempelajari data yang akan diolah. Untuk mengetahui perbedaan hasil belajar siswa yang menggunakan buku ajar dan yang tidak menggunakan buku ajar, hasilnya dapat dilihat pada tabel 4.18 dimana hasilnya menujukkan bahwa angka t-test yang mengasumsikan varian kedua populasi sama adalah sebesar 9,56. ttabel = 2,021 < thitung = 9,56 maka Ho ditolak dan H1 diterima. Dapat disimpulkan bahwa ada pengaruh penggunaan buku ajar berorientasi pendidikan karakter pada mata kuliah pembelajaran PKn SD di Program Studi S1 PGSD. Artinya, ada perbedaan nilai postest antara siswa kelompok eksperimen dan nilai postest siswa kelompok kontrol, sehingga dapat disimpulkan, nilai hasil belajar kelompok eksperimen pada kelas 5I dengan menggunakan buku ajar yang telah dikembangkan lebih baik daripada nilai hasil belajar 5D yang tidak menggunakan buku ajar.

Dari hasil analisis dapat dilihat bahwa nilai mahasiswa setelah pembelajaran dengan menggunakan buku ajar lebih baik dari pada mahasiswa yang dalam 
proses pembelajaran tidak menggunakan buku ajar. Untuk kelas 5D semua mahasiswa belum tuntas atau 100\%. Sedangkan pada kelas 5I ada 19 mahasiswa yang tuntas atau dengan persentase $95 \%$ secara klasikal dan hanya satu yang belum tuntas.

\section{E. Penutup}

\section{Simpulan}

Berdasarkan hasil penelitian dan pembahasan serta analisis data yang telah diuraikan dalam bab terdahulu, dapat disimpulkan bahwa, hasil penelitian pengembangan buku ajar berorientasi pendidikan karakter pada mata kuliah Pembelajaran PKn SD di Program Studi S1 PGSD berkategori sangat baik dan sangat layak untuk digunakan dalam proses pembelajaran pada mata kuliah pembelajaran PKn SD.

Berdasarkan hasil analisis terhadap aktivitas mahasiswa, kegiatan yang paling dominan dari aktivitas mahasiswa adalah menyampaikan pendapat/bertanya dan merespon pertanyaan baik pada saat diskusi dengan menggunakan buku ajar atau tanya jawab dengan dosen saat membahas materi buku ajar. Hasil rekapitulasi aktivitas mahasiswa selama proses pembelajaran dengan menggunakan buku ajar menunjukkan tingkat keaktifan yang baik atau aktif selama mengikuti proses pembelajaran PKn SD.

Respon mahasiswa setelah mengikuti proses pembelajaran dengan menggunakan buku ajar yang dikembangkan sangat baik dan sangat setuju apabila digunakan sebagai sumber belajar mahasiswa. Selain itu mahasiswa merespon bahwa buku ajar yang dikembangkan dapat menambah minat belajar mahasiswa dan bermanfaat untuk mengatasi kesulitan dalam belajar. Hasil belajar mahasiswa setelah dianalisis menunjukkan 95\% atau 19 mahasiswa tuntas setelah selama proses pembelajaran menggunakan buku ajar berorientasi pendidikan karakter pada mata kuliah Pembelajaran PKn SD di Program Studi S1 PGSD sebagai sumber belajar. Jika dibandingkan dengan pembelajaran tanpa menggunakan buku ajar, tes hasil belajar mahasiswa lebik baik yang menggunakan buku ajar. Efektifitas proses pembelajaran dengan menggunakan buku ajar yang telah dikembangkan diketahui melalui uji t. Dari hasil uji t menunjukkan ada pengaruh yang signifikan dari penggunaan 
buku ajar berorientasi pendidikan karakter pada mata kuliah Pembelajaran PKn SD di Program Studi S1 PGSD.

E. Penutup

\section{. Simpulan}

Berdasarkan hasil penelitian dan pembahasan serta analisis data yang telah diuraikan dalam bab terdahulu, dapat disimpulkan bahwa, hasil penelitian pengembangan buku ajar berorientasi pendidikan karakter pada mata kuliah Pembelajaran PKn SD di Program Studi S1 PGSD berkategori sangat baik dan sangat layak untuk digunakan dalam proses pembelajaran pada mata kuliah pembelajaran PKn SD.

Berdasarkan hasil analisis terhadap aktivitas mahasiswa, kegiatan yang paling dominan dari aktivitas mahasiswa adalah menyampaikan pendapat/bertanya dan merespon pertanyaan baik pada saat diskusi dengan menggunakan buku ajar atau tanya jawab dengan dosen saat membahas materi buku ajar. Hasil rekapitulasi aktivitas mahasiswa selama proses pembelajaran dengan menggunakan buku ajar menunjukkan tingkat keaktifan yang baik atau aktif selama mengikuti proses pembelajaran PKn SD.

Respon mahasiswa setelah mengikuti proses pembelajaran dengan menggunakan buku ajar yang dikembangkan sangat baik dan sangat setuju apabila digunakan sebagai sumber belajar mahasiswa. Selain itu mahasiswa merespon bahwa buku ajar yang dikembangkan dapat menambah minat belajar mahasiswa dan bermanfaat untuk mengatasi kesulitan dalam belajar. Hasil belajar mahasiswa setelah dianalisis menunjukkan 95\% atau 19 mahasiswa tuntas setelah selama proses pembelajaran menggunakan buku ajar berorientasi pendidikan karakter pada mata kuliah Pembelajaran PKn SD di Program Studi S1 PGSD sebagai sumber belajar. Jika dibandingkan dengan pembelajaran tanpa menggunakan buku ajar, tes hasil belajar mahasiswa lebik baik yang menggunakan buku ajar. Efektifitas proses pembelajaran dengan menggunakan buku ajar yang telah dikembangkan diketahui melalui uji t. Dari hasil uji t menunjukkan ada pengaruh yang signifikan dari penggunaan buku ajar berorientasi pendidikan karakter pada mata kuliah Pembelajaran PKn SD di Program Studi S1 PGSD. 
Secara garis besar tidak ada kendala mendasar yang mengganggu jalannya penelitian. Namun ada beberapa kendala yang muncul dalam proses pembelajaran yaitu saat pre-test, mahasiswa mempunyai pengalaman yang berbeda-beda dalam memahami materi pembelajaran $\mathrm{PKn}$ SD, dikarenakan mahasiswa belum sekalipun mendapatkan materi pembelajaran yang akan diberikan, pada saat diskusi, tidak semua mahasiswa mau bekerja untuk berdiskusi dan mencari solusi dari masalah yang diberikan pada buku ajar. Namun kendala tersebut dapat teratasi dengan baik oleh dosen sehingga proses pembelajaran dapat berjalan dengan baik. tersebut harus dilakukan untuk meminimalisir faktor subyektifitas dalam validasi kelayakan produk buku ajar.

\section{DAFTAR PUSTAKA}

Arikunto, S. 2009. Dasar-dasar Evaluasi Pendidikan. Jakarta: Bumi Aksara.

Belawati, Tian. 2003. Materi Pokok Pengembangan Bahan Ajar Edisi ke Satu Jakarta: Universitas Terbuka.

Bloom, Benjamin S. dkk, 1956. Taxonomy of Objective: Cognitive Domain, New York: David Mc. Kay.

Borg, W.R., \& Gall, M.D. 1983. Educational research: An introduction. (4thed). New York \& London: Longman.

Dick dan Walter Carey. 2005. The Systematic Design of Instruction. USA : Scott Foresman and Company.

Dimyati dan Mudjiono. 2006. Belajar dan Pembelajaran. Jakarta: Rineka Cipta

Djamarah, Aswan Zain,. 2006. Strategi Belajar Mengajar. Jakarta: Rineka Cipta.

Faturohman, Sobry Sutikno. 2007. Strategi Belajar Mengajar. Bandung: PT Refika Aditama.

Gagne, Robert M and Leslie J. Briggs, 1988. Principles of Instructional Design. 2nd Ed, New York: Holt Rinehart and Winstons.

Hamalik, O. 2001. Psikologi Belajar dan Mengajar. Bandung: Sinar Baru Algesindo.

Ibrahim, M. 2001. Pengembangan Perangkat pembelajaran. Jakarta: Departemen Pendidikan Nasional.

Kemp, J.E. Merrison, G.R. and Ross. 1994. Designing Efective Instruction. New York: Harper and Raw Publisher.

Keputusan Mendiknas No.36/D/O/2001, pasal 5 ayat 9 tentang pengertian buku ajar dan penyebaran buku ajar.

Majid, A. 2011. Perencanaan Pembelajaran. Bandung: PT Remaja Rosdakarya.

Makmun, A. 2004. Psikologi Kependidikan Perangkat sistem Pengajaran Moodul. Bandung: PT Remaja Rosdakarya.

Nasution dan Asmawi Zainul. 2001. Pekerti Mengajar di Perguruan Tinggi, Penilaian Hasil Belajar. Jakarta: Pusat Antar Universitas Nasution. 1982.

Berbagai Pendekatan Dalam Proses Belajar dan Mengajar. Jakarta: Bina Aksara. 2003. Metode Research. Jakarta: Bumi Aksara. 
Nur, M. 1999. Teori Belajar. Surabaya: University Press.

2008. Proses Belajar Mengajar. Jakarta: Bumi Aksara.

Purwanto, N. 2002. Prinsip-prinsip dan Teknik Evaluasi Pengajaran. Bandung: PT Remaja Rosdakarya.

Rasyid dan Mansyur. 2007. Penilaian Hasil Belajar. Bandung: CV Wacana Prima.

Riduwan. 2006. Metode dan Teknik Menyusun Tesis. Bandung: Alfabeta.

Sardiman. 2003. Interaksi Belajar Mengajar. Jakarta: Raja Grafindo.

Siti Hanim. 2011. Respon Siswa dalam Kegiatan Belajar mengajar, (Online), (http://id.shvoong.com/social-sciences/education/2143438-responsiswadalam-kegiatan-belajar/, diakses 20 Desember 2013).

Slameto. 2010. Belajar dan Faktor-faktor Yang Mempengaruhinya. Jakarta: Asdi Mahasatya.

Sudjana. 1999. Metode Statistik. Bandung: Taruna.

.2011. Penilaian Hasil Proses Belajar Mengajar. Bandung: PT Remaja Rosdakarya.

Sugiyono, 2006. Metode Penelitian Pendidikan Kuantitatif, Kualitatif dan R\&D. Bandung: Alfabeta

Sungkono, dkk. 2003. Pengembangan Bahan Ajar. Yogyakarta: FIP UNY.

Sutisna Senjaya. 2010. Pengertian Respon, (Online), (http://sutisna.com/ artikel / artikel-ilmu-sosial/pengertian-respon/, diakses 20 Desember 2013).

Syaodih, R. Ibrahim. 2010. Perencanaan Pengajaran, Jakarta: Rineka Cipta.

Tarigan, Henry Guntur. 1986. Telaah Kurikulum dan Buku Teks. Bandung: Angkasa.

Vembrianto, St. 1985. Pengantar Pengajaran Modul. Yogyakarta: Pendidikan Paramita.

Winataputra dan Budimansyah. 2007. Civiv education, Landasan Bahan Ajar dan

Kultur Kelas. Bandung: Program Studi Pendidikan Kewarganegaraan PPS UPI

\footnotetext{
ii Sri Suwartini.2017. Pengembangan Buku Ajar Berorientasi Pendidikan Karakter Pada Mata Kuliah Pembelajaran Pkn Sd Di Program Studi S1 Pgsd.Jurnal magistra Vol.29 No.100.Juni
} 